\title{
Aikuiskasvatustutkimuksen asema ja kehityssuunta Suomessa ja Saksan liittotasavallassa
}

\begin{abstract}
Pantzar Eero, 1985. Aikuiskasvatustutkimuksen asema ja kehityssuunta Suomessa ja Saksan liittotasavallassa. Aikuiskasvatus 5, 3, 96-101. - Aikuiskasvatuksen kehittyminen ja kehittäminen ovat 1970-luvulta lähtien olleet koulutusjärjestelmän ja koulutuspolitiikan keskeisiä ilmiöitä niin Suomessa kuin muuallakin. Aikuiskasvatustutkimuksen asemaan ja käyttöön ei sen sijaan ole ehditty paneutua kehittämistyössä tarmolla, jota aikuiskasvatuksen muu kehitysvauhti edellyttäisi. Tässä artikkelissa tutkimuksen asemaa ja kehityssuuntaa tarkastellaan Suomessa ja Saksan liittotasavallassa. Artikkelin taustana on kirjoittajansa keväällä 1985 valmistunut viiden maan aikuiskasvatustutkimusta käsittelevä vertaileva tutkimus. Tässä artikkelissa esiin tuleva uusi näkökulma on peräisin tutkimusmateriaalista, jonka kirjoittaja on koonnut kesällä 1985 tutkijavierailullaan Saksan liittotasavallassa.
\end{abstract}

\section{Yhteiskunnallisista viitekehyksistä}

Aikuiskasvatustoiminnan jatkuva laajeneminen luo edellytyksiä ja asettaa vaatimuksia aikuiskasvatukseen kohdistuvalle tutkimukselle. Tutkimustoiminnan tehokkuus ei synny kuitenkaan vain kohteen kehittymisestä. Käytännön tutkimustyö tarvitsee monenlaisia resursseja. Henkilöresurssien lisäksi erityisen tärkeänä on pidettävä taloudellisia voimavaroja.

Tutkimuksen voimavarojen tarkasteluun hyvän lähtökohdan antaa kansainvälinen vertailu. Tässä artikkelissa suomalaisen aikuiskasvatustutkimuksen asemaa ja kehityssuuntaa vertaillaan saksalaiseen.

Saksan liittotasavalta on Suomen kannalta merkittävä vertailuosapuoli. Ensiksikin Saksan liittotasavallan ja Suomen aikuiskasvatusjärjestelmissä on huomattavaa samanlaisuutta, jossa olennaisimpana voi pitää Volkshochschule-organisaation ja kansalaisopistojen toisiaan vastaavuutta. Toisaalta yhteiskunnalliset viitekehitykset aikuiskasvatuksen näkökul. masta ovat näissä maissa ainakin yhdessä asiassa merkittävästi toisistaan poikkeavat. Saksan liittotasavallassa nimittäin liittovaltiorakenteeseen sisältyy voimakas osavaltioiden itsesäätely aikuiskasvatusasioissa. Se on perua liittovaltion perustuslain "Kulturhoheit"'periaatteesta (Pantzar 1985, 4).

Aikuiskasvatuksen vanhin perusta on molemmissa maissa hyvin samanlainen. Kansansivistystyön syntyä, siis aikuiskasvatuksen juuria vertaillessa havaitsee kaksi asiaa. Ensiksikin valistusaatteella on ollut selvästi herättävä vaikutus kansansivistysaatteeseen. Toiseksi aikuiskasvatusorganisaation synty liittyy konkreettiseen yhteiskunnalliseen muutokseen, jota luonnehtivat edeltävinä ilmiöinä teollistuminen, väestön kasvu ja muuttoliike. Ne saivat aikaan vähitellen sosiaalista liikkuvuutta ja muodostivat pohjan kansanliikkeiden nousulle. (Vrt. Mørch Jacobsen 1982, 5; Linse 1982, 9).

Kansansivistystyön syntyvaiheisiin liittyvillä pienillä eroilla ei ole merkitystä tarkasteltaessa 
niitä nykyisen aikuiskasvatuksen juurina. Ulkopuolisten vaikutteiden ohella vertailtavien maiden keskinäinen vuorovaikutus on merkittävästi vaikuttanut siihen, että alkuvaiheessaan kansansivistystoiminta oli muodoiltaan varsin samanlaista. Kansansivistysorganisaatiot pysyivät vuosikymmeniä ulkoisesti muuttumattomina. Vasta 1950- ja 1960-luvulla uudet yhteiskunnalliset muutokset alkoivat näkyä myös aikuiskasvatusorganisaatiossa (Pantzar 1985).

\section{Aikuiskasvatuksen kehittyminen - tutkimuksen kehittyminen}

Kansansivistystyön kehittyminen aikuiskasvatukseksi on ollut seurausta ympäröivän yhteiskunnan muutoksista. Tämän päivän tilanteeseen johtanut aikuiskasvatuksen voimakas kehittyminen ei alkanut varsinaisesti ennen 1960-lukua. Aikuiskasvatustutkimuksen kehittymisen selvimmät piirteet sisältyivät noin kahdenkymmenen edellisen vuoden ajanjaksoon. Yeistäen todettuna aikuiskasvatustutkimuksen kehittyminen on jatkuvasti myöhäsyntyisempää kuin koko aikuiskasvatuksen alueella havaittava kehitys (Pantzar 1985, 81).

Saksan liittotasavallan aikuiskasvatuksen tähänastisessa kehityksessä on Siebertin mukaan erotettavissa 1960-luvulta lähtien kolme tutkimukseenkin heijastuvaa vaihetta. Hän on luonnehtinut ko. vaiheita seuraavasti:

- Pragmaattinen vaihe, joka erityisesti tutkimustoiminnassa näkyi institutionaalistumisena.

- Yhteiskuntakriittinen vaihe. Kokonaisyhteiskunnallinen makroanalyyttinen tutkimus syrjäytti mikroanalyyttisen, esim. aikuisen opettamista ja oppimista koskevan tutkimuksen.

- Sosiaaliantropologinen vaihe. Tutkimuksessa vahvistui sosiaaliteoreettinen keskustelu. Elämäntapatutkimus on tästä tyypillinen esimerkki. (Siebert 1981, 299-301).

Varsinaisesti aikuiskasvatuksen tunnustaminen osaksi julkista koulutusjärjestelmää sai alkunsa v. 1970 "'Deutscher Bildungsrat'in", koulutuskomitean suosituksesta (Strukturplan für das Bildungswesen). Kehittämistoiminta laajojen asiakirjojen muodossa jatkui v. 1973, jolloin ilmestyi "Bund-Länder Kommission'in", ,'Bildungsgesamtplan'. Siinä esitettiin toimenpiteitä myös koulutustutkimuksen osalta (Bund-Länder Kommission 1973, 7176).
Asiakirjojen vaikutus tutkimukseen on jäänyt ulkoisia puitteita koskeviksi. Sisällöllisesti tutkimus näyttää seuraavan aikuiskasvatuksen muuta kehitystä varsin hitaasti.

1970-luvun voimakas kehitys Saksan liittotasavallan aikuiskasvatuksessa näkyy myös lainsäädännön laajuutena.

Muutamissa osavaltioiden aikuiskasvatuslaeissa on myös aikuiskasvatustutkimusta koskevia määräyksiä. Ylinpäänsä lait vahvistavat osavaltioiden itsenäistä asemaa aikuiskasvatuksen osalta. Näin korostuvaan federalismiin on esitty kritiikkiä ja perätty koulutuksen erilaisten ongelmien ratkaisussa nykyistä laajempaa liittovaltion ja osavaltioiden yhteistyötä (Gernert 1975, 72; vrt. Mertineit 1970, 175). Aikuiskasvatuksessa, erityisesti tutkimuksen alueella, on yhteistyötä jo toteutettu (emt.).

Suomessa aikuiskasvatuksen viime vuosien kehityksen merkittävin vaihe alkaa 1970-luvun alusta, jolloin oikeastaan ensimmäisen kerran alettiin paneutua alueen kokonaiskehittämiseen. Kehittämisen ensimmäiseen vaiheeseen liittyy Aikuiskoulutuskomitean työ. Komitean molemmissa mietinnöissä (Kom.miet. 1971 ja 1975) korostetaan tutkimuksen merkitystä aikuiskasvatuksen kehittämisessä.

Valtioneuvoston aikuiskoulutuksen suunnittelu- ja kehittämisperiaatteita koskevassa päätöksessä mainituista toimenpiteistä (yhteensä 10 kohtaa) on yksi tutkimusta koskeva. Siinä todetaan: "Aikuiskoulutuksen kehittäminen perustetaan jatkuvalle kokeilu- ja tutkimustoiminnalle"' (Vnp 1978).

Valtioneuvoston asettaman (8.3.1979) aikuiskoulutuksen väliaikaisen kehittämisorganisaation työn II vaiheeseen kuului suunnitelman mukaan myös osaprojekti "Aikuiskoulutuksen tutkimuksen kehittäminen"'.

Projektin osatehtäviksi määriteltiin:

- Aikuiskoulutuksen tutkimuksen organisointi ja sen vaatimat resurssit

- Aikuiskoulutuksen tutkimuksen painopistealueiden selvittäminen

(Aikuiskoulutuksen kehittämisen yleissuunnitelma 1980, 36). Projekti ei kuitenkaan toteutunut, koska kehittämistoiminta on organisoitu uuteen uskoon (Aikuiskoulutusneuvosto) ennen kehittämisorganisaation yleissuunnitelman mukaisen työn II vaiheen loppuunsaamista.

Päätökseen saatettu aikuiskoulutuksen kehittämisohjelman I suunnitteluvaihe on tuottanut suuren määrän kirjallista materiaalia: komiteamietintöjä, selvityksiä ja vastaavia.

Kehittämisorganisaation kirjallisissa tuotok- 
sissa ei ole paljonkaan käsitelty tutkimuksen kehittämistä. Varsinaista tutkimustyötä koskevat ehdotukset liittyvät tutkimusorganisaation kehittämiseen (Kom.miet. 1983: 55, 199) tai tutkimuksen sisältöön (Kom.miet. 1983: 54, 185-187; Kom.miet. 1983: 62, 262).

\section{Aikuiskasvatustutkimus kansallisessa tutkimus- politiikassa}

Suomessa yleisen tutkimuspolitiikan harjoittajista ja määrittäjistä merkittävimpiin kuuluu Suomen Akatemia, joka tutkimuksen yleisen aseman parantamisen ohella määrittelee myös tutkimustoiminnan painopistealueet. Akatemia on pyrkinyt määrittelemään tutkimuksen painopistealueiksi sellaiset alueet, joilla kansallisen tiedon tarve, tutkimuksen yhteiskunnallinen merkitys sekä tutkimuksen monitieteisyys ovat huomattavia (Väisänen 1983, 13). Akatemian painopistealueiden määrittelyä voi tarkastella laajempanakin yhteiskunnan tutkimuspolitiikan kannanottona myös koulutusja aikuiskasvatustutkimuksen osalta.

Kaiken kaikkiaan koulutustutkimuksen asema näytti 1970-luvun alussa varsin hyvältä, mutta jo vuosikymmenen loppupuolelle tultaessa tilanne näytti muuttuneen (Räty 1977, 54-55).

Valtion tutkimusmenojen eri hallinnonaloille jakautumisen kehityssuunnista on selvästi havaittavissa koulutukseen ja sen tutkimukseen kohdistuvien menojen suhteellisen hidas lisäys (Korkeakoulutieto 1978, 11; Nordiska Ministerrådet 1980, 58-60; Lahti 1985). Tarkasteltaessa Suomen Akatemian tavoiteluokituksia havaitaan kasvatus ja koulutus tutkimusalueeksi, jonka merkitys toki tunnustetaan (Suomen Akatemia tiedottaa 1983, 7).

Koulutustutkimuksen vaihtelevan aseman sisällä aikuiskasvatukseen kohdistuneen tutkimuksen asema näyttä jatkuvasti olleen varsin heikko (Pantzar 1983, 3).

Suomen Akatemia laati erityisen koulutustutkimuksen kehittämisohjelmansa jo 1970luvun lopulla. Siinä todettiin koulutustutkimuksen painottuneen siihen saakka perus- ja keskiasteen yleissivistävään koulutukseen. Siksi tutkimusta katsottiin tarvittavan erityisesti muun muassa aikuiskoulutuksessa (Suomen Akatemia 1977, 48).

Tutkimuspoliittisiin ohjelmiin sisältyvien uusien alueiden esiinnousu näyttää tapahtuvan hitaasti ja vaivalloisesti. Sen todistaa jo aikuiskasvatustutkimusta koskevien puheiden ja konkreettisten tutkimuksen tukitoimenpiteiden väljä yhteys.

On ymmärrettävää, että koko tutkimuksen alueella tai erityisesti koulutustutkimuksessa asemansa vakiinnuttaneet tutkimusalueet haluavat pitää saavutetun edun. Niinpä onkin parempia aikoja odotellessa etsittävä väliaikaisia ratkaisuja. Sellaisiksi mielestäni riittää tutkimuksen merkityksen hyväksyminen ja sen mukaisten toimenpiteiden suorittaminen aikuiskoulutuksen sisäisessä kehittämisessä ja siinä käytettävillä resursseilla.

Saksan liittotasavallan tutkimuspolitiikkaa kuvaa hyvin sijoittuminen maailmassa kärkipaikoille tutkimustoiminnan edistämisessä (Suomen Akatemia 1979, 13; Nordiska Ministerrådet 1980, 58).

Koulutustutkimuksen resurssien lähde Länsi-Saksassa on yhtä monimuotoinen kuin tutkimuksen yleensäkin. Huomattava osa (noin puolet) kasvatustieteellisen tutkimuksen rahoituksesta tulee valtion budjetista (Malmquist Grundin 1975, 110; Sauer 1976, 123-128; Dieckmann-Gerhard 1980, 351-361). Yleisesti koulutustutkimuksen asema Saksan liittotasavallassa näyttää hyvältä.

Koulutustutkimuiksen sisäisiä painotuksia tarkasteltaessa havaitsee aikuiskasvatuksen tutkimuskohteena tulevan painotetuksi vaihtelevasti eri yhteyksissä. Heinzin mukaan 'Bildungskomission"' määritellessään (1974) kasvatustutkimuksen kahdeksan painopistealuetta ei mainnuit niissä aikuiskasvatusta. Eikä koulutusjärjestelmän kokonaiskehittämistä käsittelevissä asiakirjoissa (Strukturplan ja Bildungsgesamtplan) ei ole otettu selkeää kantaa koulutustutkimuksen painopisteisiin. Koulutustutkimuksen luonne on ollut alueen perustutkimukseen painottuvaa. Niinpä tutkimukseen kytkeytyvän kokeilutoiminnan osuus on verrattain pieni (Malmquist - Grundin 1975, 101).

Aikuiskasvatustutkimuksen asema Saksan liittotasavallassa on ratkaisevasti noussut aikuiskasvatustieteen aseman vahvistuessa uusien oppituolien perustamisen myötä. Niinpä aikuiskasvatustutkimuksen määrä ja laatu ovat kohonneet jo 1970-luvun alusta lähtien (Vrt. OECD 1974, 40-42 ja AUE 1980). Voimakkaimmillaan kehitys oli 1970-luvun ensimmäisinä vuosina (BMFT 1975, 81).

Kansallista tutkimuspolitiikkaa ja aikuiskasvatustutkimuksen asemaa tarkasteltaessa on otettava huomioon liittovaltiomuodon vaikutukset. Viime vuosina aikuiskasvatuksen kokonaiskehityksessä on havaittu osavaltiotason hallitusvastuun vaihdosten vaikutus. Tutki- 
mukseen vaikutukset tosin heijastuvat lievemmin tutkimuspolitiikan liittotasopainotteisuuden vuoksi. Kuitenkin muun muassa korkeakoulujen tutkimustoiminnassa hallituksen vaihdokset aiheuttavat lievää epävarmuutta ja heikon lähtökohdan pitkäjännitteiselle tutkimustoiminnalle.

\section{Tutkimustoiminnan kehityssuunta}

Aikuiskasvatustutkimuksen kehityssuuntaa arvioitaessa nousevat kiinnostaviksi kysymykset muun muassa:

- millaisiin aiheisiin (teemoihin) tutkimus kohdistuu?

- millaiseksi tutkimuksen käytäntösuhde muodostuu?

- miten tutkimuksen voimavaroja tulisi kehittää? Lisätäänkö tutkijoiden määrää vai rahoitusta tutkimukselle? Käytetäänkö resurssien jakoa tutkimuksen ohjailun välineenä vai ei?

Selkeää tutkimusteemojen määrittämistä merkittävissä puitteissa ei meillä ole tuotu julki Aikuiskoulutuskomitean esittämien käsitysten jälkeen. (Kom.miet. 1975). Tosin jopa vuosittain määritellään kansalais- ja työväenopistojen erityisvaltionapuun liittyen kokeilutoiminnan painopistealueet. Sen merkitys rajoittuu kuitenkin vain suppealle alueelle ja merkitys koko aikuiskasvatuksen kannalta on siksi pieni. (Ks. Pantzar 1985, 121-122).

Mielenkiintoista on havaita, ettei Saksan liittotasavallassakaan ole harjoitettu jatkuvaa kansallista aikuiskasvatustutkimuksen painopisteteemojen määrittelyä. Laajemmissa puitteissa - samoihin aikoihin kuin meillä Aikuiskoulutuskomitea määritti tutkimuksen painopisteet - määritellyt keskeiset tutkimusteemat muistuttavat hyvin paljon Suomessa esitettyjä. Poikkeuksena linjasta on nähtävä se, että Saksan liittotasavallassa ammatilliseen aikuiskoulutukseen kohdistuvan tutkimuksen merkitys tuli esiin aikaisemmin kuin Suomessa. (Kempte 1972, 2-3: vrt. Kom.miet. 1975).

Tutkimuksen teemoja tarkastellessa näkyy selvästi laajan, ammatillisen aikuiskoulutukseen kohdistuvan tutkimuksen merkityksen kasvu sekä meillä että Saksan liittotasavallassa. Toisaalta on nähtävissä myös se, että jo nyt Saksan liittotasavallassa tärkeiksi nousseet tutkimuskohteet - esim. vaihtoehtoinen didaktiikka ja erityisryhmät - ovat meillä vasta tu- lossa aiempaa tärkeämmiksi tutkimusteemoiksi.

Tutkimuksen käytäntösuhde - pragmaattisuus - on aikuiskasvatuksen piirissä ollut jatkuvasti - välillä kiivaankin - keskustelun aiheena. Sinänsä tieteenalan painottunutta pragmaattisuutta ei ole asetettu kyseenalaiseksi. Ongelmana on pikemminkin ollut löytää tutkijoiden, suunnittelijoiden ja käytännön aikuiskasvattajien yhteinen linja tutkimuksen hyväksikäyttöä koskevissa kysymyksissä.

Erityisesti yliopistojen tutkijat saavat toistuvasti kuulla tekevänsä tutkimusta, jolla ei ole käyttöä. Tutkijat saattavat vastata sanomalla tekevänsä aikuiskasvatuksen teoriaa kehittävää perustutkimusta. Tämä ristiriita on tunnettu niin meillä Suomessa kuin Saksan liittotasavallassa. Saksalaista keskustelua käsittelevässä tuoreessa artikkelissa on prof. Horst Siebert todennut, ettei teoria kuitenkaan ole välttämättä kaikki ja vain se, mitä korkeakouluissa ajatellaan ja kirjoitetaan. Hänen mukaansa samaan aikaan kuin korkeakouluissa saatetaan tuottaa teoreettisesti köyhää tutkimusta, teorian kehittämistä tapahtuu myös korkeakoululaitoksen ulkopuolella (Siebert 1985, 129).

Sinänsä aikuiskasvatuksen alueella teorian kehittäminen ja perustutkimus laajemmin ovat tieteenalan nuoruuden ja kehitysvaiheen huomioonottaen tärkeitä alueita (Sonderheft 1970, 14, Schulenberg 1982, 65).

Viime vuosien kehitystä tarkastellessa havaitsee uutena asiana aikuiskasvatukseen kohdistuvan tutkimuksen lisääntymisen myös aikuiskasvatustieteen ulkopuolella. Ilmiöön voi suhtautua kahdella tavalla. On mahdollista ajatella naapuritieteenalojen edustajien huomanneen aikuiskasvatukseen kohdistuvan tutkilmuksen nousseen arvossa ja olevan siksi kiinnostavaa. Toisaalta voi tyytyväisenä nähdä aikuiskasvatustutkimuksen perustan laajenevan ja näin tuottavan uutta mm. perustutkimukseen (esim. Schulenberg em.). Laajentunutta kiinnostusta aikuiskasvatukseen tutkimuksen kohdealueena tulisi käyttää mahdollisimman tehokkaasti hyväksi etsimällä ja käyttämällä muilla tieteenaloilla tehtyjä tutkimuksia ja niiden tuloksia vahvistamaan ja laajentamaan aikuiskasvatuksen omaa teoriaa ja tutkimusta. Näin toimimalla voidaan aikuiskasvatuksen omaa perustutkimusta resurssiniukkuuden aikana kohdistaa alueille, joita ei muilla tieteenaloilla tutkita.

Käytäntöä palvelevaksi ja siten pragmaattiseksi on yleensä ymmärretty ns. sovellettava (soveltava) tutkimus. Samoja tarkoitusperiä 
on nähty palvelevan myös ns. kokeilutoiminnan.

Tutkimuksen sovellettavuuden arviointi on monesti vaikea tehtävä. On tosiasia, että korkeakoulujen ja aikuiskasvatuksen kentän välillä on selviä kommunikaatio-ongelmia. Ne liittyvät juuri tutkimuksen käyttökelpoisuuden arviointiin. Kentällä - mutta myös hallinnossa - odotetaan ehkä liian valmiita tuloksia. Saattaa olla osittain myös niin, että korkeakouluissa asetetaan liian suuret vaatimukset tutkimustulosten käyttäjille tulosten käytäntöön soveltamisessa (Siebert 1978, 126-128; Pantzar 1985, 20-23).

Aikuiskasvatustutkimuksen kehityksessä on selvästi havaittavissa suunta välittömästi hyödyksi käytettävän tutkimuksen lisääntymiseen. Vaikka kokeilutoiminta jätetään tarkastelun ulkopuolelle, on se nähtävissä koulutuksen suunnittelijoiden pyrkimys lisätä tutkimusta, joka on käytettävissä aikuiskoulutuksen ja aikuisopetuksen kehittämisessä. Aikuiskoulutuspoliittisen kehittämisen painopisteohjelmat näyttävät sekä meillä että Saksan liittotasavallassa suuntaavan jo nyt aikuiskasvatustutkimusta. Se merkinnee muun muassa ammatillisen aikuiskoulutuksen alueelle kohdistuvan tutkimuksen lisääntymistä. Varsinaista tutkimustoimintaa ennen kehittämispoliittiset suuntaviivat näkynevät kokeilutoiminnan alueella (Kolwe-Jung et al. 1980, 15-17). Tutkimusta suorittavien onkin pohdittava tarkkaan, tehdäkö tutkimusta, jolle on tarjolla voimavaroja vai tutkimusta, joka ulkopuolisista houkuttimista ja sanktioista riippumatta nähdään tärkeäksi. Joka tapauksessa tarttumalla tarjoittuihin tilaisuuksiin voidaan aikuiskasvatustutkimuksen asemaa kokonaisuudessakin parantaa.

Tutkimuksen kehittämisen ehtona ylipäänsä on resurssien kehittäminen. Se voi tapahtua kahta päätietä: lisäämällä tutkimusrahoitusta tai lisäämällä henkilöresursseja. Rahoituksen yksinomainen lisääminen tuo aina eteen kysymyksen rahoituksen mahdollisesta vaikutuksesta tutkimuksen suuntaan. Taloudellisia resursseja voidaan lisätä tutkimukseen vapaasti käytettäväksi tai siten, että rahoitukseen sisältyvin ehdoin tutkimuksen kohde rajataan. Rahoituksen lisäämiseen suomalaisessa aikuiskasvatustutkimuksessa on kiistaton tarve. Tutkijakeskeisen tutkimuksen kehittymisen varmistamiseksi on pyrittävä lisäämään myös henkilöresursseja. Valitsemalla kehittämisen linjaksi yhdistetty taloudellisten ja henkilöresurssien lisääminen voidaan taata teoriaa kehittävän perustutkimuksen ja koulutussuunnittelua palve- levan sovellettavan tutkimuksen asema ja edistyminen.

\section{Lähteet}

Aikuiskoulutuksen kehittämisen yleissuunnitelma 1980. Aikuiskoulutuksen johtoryhmä. Helsinki.

AUE 1980. Studienmöglichkeiten der Erwachsenenpädagogik an der Hochschulen der Bundesrepublik Deutschland und West-Berlins. MAEB 20. AUE: Hannover.

BMFT 1975. Fünfter Forschungsberichte der Bundesregierung. Der Bundesminister für Forschung und Technologie. Bonn.

Bund-Länder Kommission 1973, Bildungsgesamtplan. Bd 1. Ernst Klett: Stuttgart.

Dieckmann B - Gerhard R. 1980, Weiterbildungsforschung. In: Wörterbuch der Weiterbildung. Kösel: München. 351-360.

Gernert W 1975, Das Recht der Erwachsenenbildung als Wciterbildung. Reinhardt: München.

Kempte H. 1972, Erwachsenenbildungforschung im Rahmen des Bundesinstitut für Berufsbildungsforschung. In: Zeitschrift für Berufsbildungsforschung $2,1-8$.

Kom.miet. 1971. Aikuiskoulutuskomitean I osamietintö. Helsinki.

Kom.miet. 1975. Aikuiskoulutuskomitean II osamietintö. Helsinki.

Kom.miet. 1983: 64, Aikuisten ammatillisen peruskoulutuksen toimikunnan mietintö. Helsinki.

Kom.miet. 1983: 55, Ammatillisen lisäkoulutuksen toimikunnan mietintö. Helsinki.

Kom.miet. 1983: 62, Jatkuvan koulutuksen toimikunnan mietintö. Helsinki.

Korkeakoulutieto 1978, Tutkimus- ja kehitystyön rahoitus $1970-78$. Korkeakoulutieto 3, 9-12.

Kolwe-Jung G. et al. 1980, Modellversuche der Weiterbildung. AfEB 16. Heidelberg.

Lahti T. 1984, Voimavarojen typistys vaarantamassa yliopistojen tason. Helsingin Sanomat 20.8. 1984.

Linse B. 1982, Von der Volkbildung zur Erwachsenenbildung. In: Arbeitshilfe für die Erwaschsenenbildung $13,5-18$.

Malmquist E. - Grundin H. 1975, Educational Reseach in Europe Today and Tomorrow. GWK Gleerup: Lund.

Mertineit W. 1970, Bildungsrecht und Recht auf Bildung. In: Tietgens H. et al., Zukunftsperspektiven der Erwachsenenbildung. Westermann: Braunschweig.

Mørch Jacobsen K. 1982, Adult Education in the Nordic Countries. Nordic Academy of Adult Education: Kungälv.

Nordiska Ministerrådet 1980, Ökad nordisk forskningssamarbete. Stockholm.

OECD 1974, The Educational Situation in OECD Countries. OECD: Paris.

Pantzar E. 1983, Aikuiskasvatuksen uusia suuntia: Vertaileva analyysi Suomen ja Pohjoismaiden tutkimus- ja kehittämistoiminnasta. Tampereen 
yliopisto. Aikuis- ja nuorisokasvatuksen laitoksen julkaisuja 19.

Pantzar E. 1985, Aikuiskasvatustutkimus viidessä maassa: vertaileva tutkimus aikuiskasvatustutkimuksen yleisistä lähtökohdista ja tehdystä tutkimuksesta Saksan liittotasavallassa, Suomessa ja muissa Pohjoismaissa, Tampereen yliopisto Aikuis- ja nuorisokasvatuksen laitoksen julkaisuja 20.

Răty T. 1977, Valtion tutkimusmenot vuosina 1970-77. Suomen Akatemian julkaisuja 11. Helsinki.

Sauer J. 1976, Erwachsenenbildung: Stand und Trend der Forschung in der Bundesrepublik Deutschland. Vanderhoech \& Ruprecht: Gobttingen.

Schulenberg W. 1982, Wissensproduktion und Wirkungsgefüge. Überlegungen zu der Veränderungen in der Erwachsenenbildungsforschung. In: Becker H. u.a., Wissenschaftliche Perspektiven zur Erwachsenenbildung. Westermann: Braunschweig. 65-72.

Siebert H. 1978, Die Praxisrelevanz der Erwachsen- enbildungsforschung. Angewandte Sozialforschung 3, 125-134.

Siebert H 1981, Der Beitrag der Wissenschaft der Weiterbildung. Hessische Blătter für Volksbildung 4, 297-301.

Siebert H. 1985, Stand der theoretischen Diskussion in der Erwachsenebildung. Pädagogische Rundschau. Vol. 39, 129-141.

Sonderheft 1970. Arbeit und Leben 11. Solingen.

Suomen Akatemia 1977, Koulutustutkimuksen kehittämisohjelma. Suomen Akatemian julkaisuja 1. Helsinki.

Suomen Akatemia 1979, Kansainvälisiä tietoja tutkimusrahoituksesta. Suomen Akatemia tiedottaa 4, 13.

Suomen Akatemia tiedottaa 1983. Tilastotietoja Suomen Akatemian toiminnasta vuonna 1982. Suomen Akatemia tiedottaa 3, 4-8.

Vnp 1978, Valtioneuvoston păätös aikuiskoulutuksen suunnittelu- ja kehittămisperiaatteista, 7.6. 1978.

Văisănen A. 1983, Tutkimuksen edistäminen. Korkoakoulutieto $8,11-14$. 